\title{
INQUÉRITO POLICIAL: ANÁLISE PRÁTICA DO PROCEDIMENTO
}

\section{ARTIGO DE REVISÃO}

MARCONDES, Diego Henrique ${ }^{1}$, ALCÂNTARA, Denise ${ }^{2}$

MARCONDES, Diego Henrique. ALCÂNTARA, Denise. Inquérito policial: análise prática do procedimento. Revista Científica Multidisciplinar Núcleo do Conhecimento. Ano. 07, Ed. 02, Vol. 02, pp. 105-121. Fevereiro de 2022. ISSN: 24480959, Link de acesso: https://www.nucleodoconhecimento.com.br/lei/pratica-doprocedimento

\section{RESUMO}

Contexto: $\mathrm{O}$ inquérito policial são as diligências realizadas pela autoridade policial na apuração de infrações penais. $O$ procedimento é extremamente importante na apuração dos fatos para determinar se houve uma infração penal e de quem é a autoria. Assim, o procedimento dá condições para que a acusação e a defesa procedam de forma justa e democrática. Problema: como ocorre o desenvolvimento do inquérito policial e quais são suas principais características? Objetivo: $\mathrm{O}$ estudo tem como principal objetivo discorrer sobre como ocorre o desenvolvimento do inquérito policial, onde será abordado conceitos teóricos e quais são suas características e suas finalidades, como é feito uma abordagem de cunho teórica e jurídica. Este trabalho também irá apresentar e discutir quais são as perspectivas práticas como diligências e quais são as consequências diretas. Metodologia: A metodologia de pesquisa foi composta de um levantamento bibliográfico utilizando bancos de dados, tal como o Google acadêmico e a plataforma Scielo, não se

${ }^{1}$ Pós-graduando dos cursos de especialização em Direito. Penal e Processo Penal e Criminologia pela Faculdade de Venda Nova do Imigrante-FAVENI, Bacharel em Direito pela Universidade Anhanguera. ORCID: 0000-0002-9007-8957

2 Orientador.

RC: 106499

Disponível em: https://www.nucleodoconhecimento.com.br/lei/pratica-doprocedimento 
limitando a essas fontes, também foi consultado livros e sites que tratam da problemática de estudo. Considerações Finais: O presente trabalho teve por objetivo discutir os principais aspectos do inquérito policial, onde foi evidenciado a importância do mesmo para o setor judiciário, contribuindo para dar respaldos robustos para propor uma ação penal. Foi apresentado como se desenvolve o inquérito policial e, também, descreveu-se quais são as principais informações envolvidas nesse procedimento e quais são as suas implicações para o setor. A temática de estudo é extremamente rica e diversos estudos complementares podem ser desenvolvidos com o intuito de refutar ou corroborar os achados e esse estudo pode ser também usado para desenvolver materiais de divulgação que venham a demonstrar a importância do inquérito policial.

Palavras-chave: Inquérito Policial, Jurisdição Policial, Persecução Penal.

\section{INTRODUÇÃO}

O presente trabalho tem por escopo a análise prática do instrumento mais importante quando o assunto é persecução penal: o inquérito policial. Apesar de ser dispensável em algumas hipóteses, é com esse procedimento administrativo que, geralmente, se dá início à persecução penal (DUARTE, 2017).

De conhecimento fundamental para todos os operadores do direito, principalmente para os advogados que militam na esfera criminal e os atuantes nas áreas de segurança pública, o inquérito policial tem muitas "nuances", que por vezes são "esquecidas" durante o período acadêmico (JUNIOR, 1998).

Dessarte, o inquérito policial é um procedimento imprescindível na apuração dos fatos e na determinação se houve infração, demonstrando a sua extrema importância para tornar o sistema judiciário justo e imparcial. Entretanto, como o procedimento deve ser feito, quais são as principais informações que devem ser levadas em consideração na execução desse procedimento, quais são as suas implicações, dentre outras. Assim, como o inquérito policial deve ocorrer e quais são as suas principais características?

Disponível em: https://www.nucleodoconhecimento.com.br/lei/pratica-doprocedimento 
O estudo tem o objetivo discorrer sobre como se ocorre o desenvolvimento do inquérito policial, abordando conceitos teóricos e quais são suas características, levando em consideração a literatura disponível, e descrever quais são as suas finalidades, como é feito uma abordagem de cunho teórica e jurídica. Também será apresentado e discutido quais são as perspectivas práticas como diligências e quais são as consequências diretas

Um dos pontos principais é explanar sobre como a polícia judiciária utiliza, de acordo com a literatura, esse instrumento, tendo como finalidade a descoberta da materialidade e autoria dos mais diversos tipos de delito, que servirá de base para a ação penal ou às possíveis medidas cautelares que vierem a ser indispensáveis na ocorrência.

O ciclo completo de polícia judiciária compreende a habilidade da mesma corporação policial em realizar a prevenção, a repressão criminal, a investigação, o levantamento da materialidade e autoria delitiva e, logo após conclusão do inquérito policial, encaminhá-los ao poder judiciário (JUNIOR, 2016).

A atividade de polícia judiciária é determinante no exercício do poder investigativo. $\mathrm{E}$ ela é a responsável por apurar infrações nas quais o policiamento ostensivo foi incapaz de impedir ou até mesmo não sabia da existência, além de ser fundamental para a investigação criminal e consecução da justiça, bem como para o esclarecimento da possível verdade real por trás dos acontecimentos (JUNIOR, 1998) (AVENA, 2017).

Para tal, é altamente dificultoso, com as complexidades das práticas delituosas atuais, imaginar um cenário onde esta atividade não se utilizasse de um instrumento técnico administrativo como o inquérito policial.

Conforme trata Picolin (2007), o inquérito policial consiste em todas as diligências necessárias para o descobrimento dos fatos criminosos, de suas circunstâncias e dos seus autores e cúmplices, devendo ser reduzido a instrumento escrito. 
Sendo assim, o inquérito policial tem como objetivo apurar a autoria e materialidade das infrações penais investigadas, servindo de instrumento influenciador de convicção do titular da ação penal e para isso a polícia judiciária realiza diversas diligências para recolhimento de provas (LIMA, 2017).

Para Júnior (1998), o inquérito policial é um procedimento destinado a reunir elementos para apuração da infração penal e sua autoria. É um conjunto de diligências realizadas pela polícia judiciária, de modo que o titular da ação penal (Ministério público ou ofendido) ingresse em juízo para que seja a lei aplicada ao caso concreto.

Estas etapas são estritamente importantes com a finalidade de se conseguir qualificar o réu para então dar prosseguimento à denúncia ou queixa, sendo rejeitada a ação por manifesta inépcia formal caso não cumpra o requisito.

Conforme disposto no art. 12, do Código de Processo Penal, "o inquérito policial acompanhará a denúncia ou queixa sempre que servir de base a uma, ou outra" (BRASIL, 1941), portanto, quando não se adequar de suporte para o oferecimento da imputação, o mesmo não será impreterível.

Por conseguinte, o inquérito policial é um tópico extremamente relevante e importante para o setor judiciário, isso demonstra a importância de uma pesquisa sobre como é a prática do procedimento, segundo a literatura disponível, e quais são as suas finalidades e implicações. A metodologia aplicada neste estudo será composta por um levantamento bibliográfico, onde serão usados bancos de dados que indexam publicações científicas, tal como o Google acadêmico e a plataforma Scielo, não se limitando a essas fontes, também será considerado livros e sites que tratem sobre a problemática. As principais informações contidas nos trabalhos serão abordadas e discutidas neste trabalho.

Assim, este presente trabalho irá discutir aspectos importantes relacionados ao procedimento e como ele é imprescindível para analisar as evidências, oferecendo grande respaldo para propor uma ação penal. 


\section{DESENVOLVIMENTO}

\subsection{BREVES APONTAMENTOS SOBRE O INQUÉRITO POLICIAL}

O principal instrumento administrativo na fase de investigação, o Inquérito Policial é fundamental para as atividades de polícia judiciária na persecução penal em busca da verdade real, sendo imperioso em todas as diligências necessárias para o descobrimento dos fatos criminosos, da materialidade, autoria e suas circunstâncias (LIMA, 2017).

O inquérito Policial, instrumento de estudo do presente trabalho, se baseia no sistema inquisitório, tendo a ampla defesa e contraditório mitigados. Diferente do Processo Penal vigente no ordenamento jurídico brasileiro, o qual tem por base o sistema acusatório, tendo como características ter em pessoas distintas as funções de julgar, acusar e defender (JUNIOR, 1998).

Com esses apontamentos iniciais, cabe uma ressalva quanto ao recente posicionamento do STF no que tange ao procedimento do Inquérito Policial. Com a publicação da súmula vinculante $n^{\circ} 14$, o STF (2009) fixou entendimento que: "É direito do defensor, no interesse do representado, ter acesso amplo aos elementos de prova que, já documentados em procedimento investigatório realizado por órgão com competência de polícia judiciária, digam respeito ao exercício do direito de defesa".

Cabe salientar que esse entendimento não significa dizer que o Inquérito abarque ampla defesa e contraditório, mas sim que o defensor possa ter acesso às provas já produzidas, mas que sua obtenção a diligências ainda em andamento seja vedada.

\subsection{FINALIDADE DO PROCEDIMENTO}

Tendo como principal fundamento a apuração da autoria e materialidade do delito investigado, o Inquérito Policial tem por finalidade ser o instrumento fundamental na 
busca por provas que auxiliem o titular da ação penal, o Ministério Público, bem como influenciar no conjunto probatório apresentado ao douto julgador (JUNIOR, 1998).

Para isso, a polícia judiciária, sob o comando do delegado de polícia, realiza diversas diligências de modo a conseguir provas irrefutáveis da materialidade e da autoria. Vale dizer que, ao falar em materialidade, se busca provas reais que o delito foi cometido e após a conviç̧ão de que o delito existiu, busca-se o autor, para que possa ser qualificado e posteriormente indiciado (JUNIOR, 2016).

Todo esforço da polícia judiciária nessa fase da persecução penal se faz necessário a fim de se evitar que pessoas inocentes sejam indiciadas e levadas a julgamento por delitos que não cometeram, ferindo assim a dignidade da pessoa humana.

\section{3 (IN)DISPONIBILIDADE DO INSTRUMENTO}

Ao contrário do Juiz e do Promotor que possuem como competência sua jurisdição, o Delegado de Polícia detêm circunscrição, o que significa que em uma mesma comarca pode haver várias delegacias de polícia, não obstante o delegado não responderá por todas as comarcas, mas somente por uma área determinada, a circunscrição do espaço em que atua. Essa regra possui exceções, como as delegacias especializadas, que atuam em qualquer crime que seja seu fim específico dentro da sua cidade, independentemente de sua circunscrição (JUNIOR, 1998).

Após a apuração e identificação das fontes de provas de materialidade do delito e de sua autoria, o conjunto probatório é encaminhado ao titular da ação penal para que sirva de base à denúncia ou queixa (PACELLI, 2017). No entanto, vale ressaltar que o Promotor Público ou o particular (nos casos em que a ação penal seja privada), podem promover o ato penal sem o Inquérito Policial, tendo a fase probatória somente na ação penal.

Por este motivo, o Inquérito Policial não é instrumento indispensável à propositura da ação penal, e por ter esse caráter auxiliar na averiguação não se torna relevante, visto

Disponível em: https://www.nucleodoconhecimento.com.br/lei/pratica-doprocedimento 
que, se o ministério público ou o ofendido (nos casos de ação penal privada), obtiver de meio lícito um conjunto mínimo de informações que indiquem serem capazes de auferir a autoria e materialidade do delito em debate, o procedimento poderá ser dispensado sem maiores problemas (PACELLI, 2017).

É possível concluir do excerto acima que o Inquérito Policial é instrumento dispensável, porém, por se tratar de um procedimento administrativo próprio das polícias judiciárias, as quais são especializadas na busca de elementos comprobatórios de autoria e materialidade da conduta delitiva, a investigação se mostra de suma importância no recolhimento de provas e na busca da verdade.

\subsection{DAS CARACTERÍSTICAS DO INQUÉRITO POLICIAL}

Como principal instrumento de investigação pré-processual, é de suma importância analisar as características que norteiam o inquérito policial, as quais serão analisadas ao longo deste tópico (PATRIOTA, 2017).

\subsection{PROCEDIMENTO ESCRITO}

Nos termos do art. 9ำ do CPP, o Inquérito Policial deve ser escrito. De acordo com o art. 9: todas as peças da sindicância policial serão, num só processados, reduzidas a anotação ou datilografadas e, neste caso, rubricadas pela autoridade (PATRIOTA, 2017).

No entanto, verifica-se que atualmente alguns Estados passaram a adotar o Inquérito Policial Eletrônico, de modo que determinados atos passaram a ser armazenados no bojo do procedimento de outra maneira, a exemplo de uma gravação de áudio. Assim, é inegável que o avanço da tecnologia acaba por mitigar a característica em estudo.

\section{6 (IN) DISPONIBILIDADE}

Após a instauração do procedimento, a autoridade policial não pode arquivar o instrumento, pois não é o titular da ação penal. Neste ponto, é preciso uma análise RC: 106499

Disponível em: https://www.nucleodoconhecimento.com.br/lei/pratica-doprocedimento 
cuidadosa, pois as normas estabelecidas mudam o panorama processual penal, assim o procedimento ainda vigente e o processo previsto nos artigos 28 e 28 -A do Código de Processo Penal, aprovados com o Pacote Anticrime, os quais tiveram a aplicação suspensa em sede liminar pelo Excelentíssimo Ministro do Supremo Tribunal Federal, Luiz Fux, no dia 22 de janeiro deste ano, na condição de relator das ADIs 6.298, 6.299, 6.300 e 6305 (STF, 2001).

Com as alterações feitas pela lei 13.964/2019, que como dito acima se encontram suspensas pelo Supremo Tribunal Federal, o arquivamento do Inquérito Policial passou a ser privativo do Ministério Público, titular da ação penal. Conforme previsto no art. 28 e 28-A do Código de Processo Penal, o Ministério Público deve comunicar a vítima, o acusado, o delegado e remeter os autos para revisão ministerial. Se a vítima ou seu representante não concordar com o arquivamento, faz um pedido de revisão no prazo de 30 dias. Cabe frisar que se o crime for em detrimento da União, Estados e municípios a revisão poderá ser promovida pela chefia do órgão (BRASIL, 1941).

O procedimento ainda vigente previsto no artigo 28 do Código de Processo Penal prevê que o Ministério Público, na condição de titular da ação penal, é quem pode requisitar ao juiz o arquivamento do Inquérito Policial (BRASIL, 1941). Nesse caso, se o magistrado concordar com o posicionamento do parquet, o inquérito será arquivado. Caso o magistrado discorde com as alegações do promotor, remeterá os autos para o Procurador-Geral, o qual terá três alternativas: designar outro membro do Ministério Público para que ofereça a queixa; ele mesmo oferecer a denúncia ou concordar com o arquivamento, sendo o juiz obrigado a acatar.

\subsection{SIGILO}

O sigilo do Inquérito Policial se mostra necessário não só à elucidação dos fatos, mas também para proteção para a pessoa que figura como investigado no procedimento, pois, assim se evita a sua exposição pública (PATRIOTA, 2017). Como descrito por Patriota (2017), o sigilo, pode ser entendido de duas formas:

RC: 106499

Disponível em: https://www.nucleodoconhecimento.com.br/lei/pratica-doprocedimento 
- Sigilo externo: atinge toda a sociedade, tem a finalidade de evitar a divulgação de informações essenciais e, por consequência, eventual prejuízo às investigações e à própria pessoa do investigado.

- Sigilo interno: atinge aos que atuam no feito. Cabe ressaltar que o magistrado e o representante do Ministério Público possuem amplo e irrestrito acesso aos autos do Inquérito, não se Ihes aplicando o sigilo interno.

Nesse sentido, firmou-se entendimento que, em sede de Inquérito Policial, devem ser respeitadas as prerrogativas dos advogados de acesso aos autos, segundo a lei $n^{\circ}$ 8906/94 (estatuto da OAB), súmula vinculante $n^{\circ} 14$ e art. $8^{\circ} \S^{\circ} 3^{\circ}$ e art. 23 lei $n^{\circ}$ 12850/2013. O sigilo interno se aplica ao advogado, nas situações de diligências em andamento que ainda não tenham sido documentadas (BRASIL, 2016).

O Supremo Tribunal Federal (2009) se posicionou, através da Súmula Vinculante $\mathrm{n}^{\circ} 14$, estabelecendo o quanto segue:

Súmula vinculante 14: É direito do defensor, no interesse do representado, ter acesso amplo aos elementos de prova que, já documentados em procedimento investigatório realizado por órgão com competência de polícia judiciária, digam respeito ao exercício do direito de defesa.

No mesmo sentido, no dia 12 de janeiro de 2016, foi publicada a lei n. 13.245/16, que alterou o Estatuto da OAB (BRASIL, 2016), que passou a vigorar com a seguinte redação:

Art. $7^{\circ}$ (...) XIV - Examinar, em qualquer instituição responsável por conduzir investigação, mesmo sem procuração, autos de flagrante e de investigações de qualquer natureza, findos ou em andamento, ainda que conclusos à autoridade, podendo copiar peças e tomar apontamentos, em meio físico ou digital. Imperioso concluir que o advogado pode ter acesso aos autos do Inquérito mesmo sem procuração, a qual só será exigida no caso de procedimento que tramita sob segredo de justiça decretado judicialmente, nos termos do par.

(...) XXI - Assistir a seus clientes investigados durante a apuração de infrações, sob pena de nulidade absoluta do respectivo interrogatório

RC: 106499

Disponível em: https://www.nucleodoconhecimento.com.br/lei/pratica-doprocedimento 
ou depoimento e, subsequentemente, de todos os elementos investigatórios e probatórios deles decorrentes ou derivados, direta ou indiretamente, podendo, inclusive, no curso do respectivo aprimoramento: A) apresentar razões e quesitos; $\S 10$. Nos autos sujeitos a sigilo, deve o advogado apresentar procuração para o exercício dos direitos de que trata o inciso XIV.

As novas previsões do Estatuto da $O A B$ ampliam o acesso do advogado às investigações preliminares, dando mais condições para defesa do acusado, e assegura ao defensor o direito de estar presente no interrogatório e nos depoimentos garantindo a ampla defesa (SOUZA, 2016).

\subsection{PROCEDIMENTO DISCRICIONÁRIO E INQUISITIVO}

Conforme Capez (2016):

Caracteriza-se como inquisitivo o procedimento em que as atividades persecutórias se concentram nas mãos de uma única autoridade, a qual, por isso, prescinde, para a sua atuação, da provocação de quem quer que seja, podendo e devendo agir de ofício, empreendendo, com discricionariedade, as atribuições fundamentais aos esclarecimentos do crime de sua autoria.

A autoridade policial tem autonomia para conduzir o Inquérito Policial, ou seja, existe uma oportunidade de autuação conferida pela lei ao Delegado, que exerce assim o seu juízo de conveniência e oportunidade. Ao contrário do que ocorre na fase processual, em que existe um procedimento a ser seguido com uma série de atos prédeterminados pela lei, o Delegado conduzirá a investigação de acordo com a sua convicção (JUNIOR, 1998).

Apesar de haver discricionariedade em suas tomadas de decisões, a Autoridade Policial não pode negar a realização do exame de corpo de delito, pois, quando a infração penal deixar vestígios, é indispensável a execução do exame de corpo de delito, cuja realização não pode ser indeferida pela Autoridade Policial. 
Importante frisar que existe apenas uma perícia que não pode ser requisitada diretamente pelo Delegado de Polícia, que é o incidente de sanidade mental, cabendo à Autoridade Policial representar ao magistrado para a instauração da ocorrência.

\subsection{PROCEDIMENTO DISPENSÁVEL}

De acordo com a doutrina tradicional, o Inquérito Policial é dispensável, pois, o Ministério Público pode oferecer a peça acusatória, desde que já possua elementos para tanto, independentemente do Inquérito Policial. Em outras palavras, a inquirição é dispensável para o oferecimento da denúncia (JUNIOR, 1998) (JUNIOR, 2016). Todavia, a maioria dos crimes necessita de procedimento investigativo, sendo a polícia judiciária o órgão competente e especializado para esse fim.

\subsection{PROCEDIMENTO OFICIAL E OFICIOSO}

O inquérito policial é conduzido por um órgão oficial, que é a polícia judiciária, podendo ser tanto a Polícia Civil, quanto a Federal (JUNIOR, 1998). Mas cabe ressaltar que é privativo desses dois órgãos. Além disso, tem a característica de ser oficioso, pois, todos os atos são praticados de ofício, não exigindo um caráter oficial.

\subsection{ANÁLISE PRÁTICA DO PROCEDIMENTO}

Nas palavras do professor Neto (2018), a doutrina tradicional sempre destacou que a principal função do inquérito policial seria reunir elementos suficientes sobre o fato criminoso para que o titular da ação penal pudesse exercer a sua pretensão acusatória.

Portanto, para que a finalidade do Inquérito Policial seja alcançada, uma das previsões do Código de Processo Penal, em seu artigo $7^{\circ}$, que trata sobre a possibilidade da reprodução simulada dos fatos, desde que não seja contrária à moralidade ou a ordem pública, sendo uma das possíveis medidas que conseguem ser realizadas durante a etapa da persecução penal e que contribuem na apuração dos fatos, e ao passo que

Disponível em: https://www.nucleodoconhecimento.com.br/lei/pratica-doprocedimento 
o artigo 6e elenca um rol exemplificativo sobre algumas das diligências que devem ser efetuadas pela autoridade policial, não existindo uma ordem pré-definida ou sequer obrigatoriedade, como veremos adiante (BRASIL, 1941).

O artigo $6^{\circ}$ do Código de Processo Penal pátrio trata sobre a preservação do local do crime, pela autoridade policial, até a chegada dos peritos. Cumpre aqui salientar que a autoridade não trabalha sozinha, mas sim com uma equipe, cabendo a todos os envolvidos assegurar a correta preservação para que os peritos possam coletar o maior número de vestígios possíveis, colaborando assim com a busca pela autoria e materialidade dos fatos (BRASIL, 1941) (MARCÃO, 2016).

O mesmo artigo prevê que, após a liberação dos peritos, deve a autoridade policial apreender os objetos que tiverem relação com o fato criminoso, aqueles que possam ter utilidade no curso da investigação para o esclarecimento dos fatos.

O inciso IV do referido artigo denota a óbvia importância de, sempre que possível, ouvir o ofendido para a elucidação do caso, visando a descoberta do autor ou de quem se imagina que seja o autor e as possíveis provas que se tenha conhecimento, sempre reduzindo a termo suas declarações. Em sendo intimado para esse fim e não comparecer sem um motivo justo poderá o indivíduo ser conduzido à presença da autoridade por meio de condução coercitiva, afinal, é de se imaginar que a vítima poderá reunir informações cruciais a respeito da ocorrência do delito e da dinâmica dos fatos (MARCÃO, 2016).

Da mesma maneira, o inciso $\mathrm{V}$ traz a importância de se ouvir o indiciado sempre que for possível, regulando ainda que o inquérito deve ocorrer no que for aplicável dentro dos moldes do interrogatório feito pela Autoridade Judicial (artigos 185 a 196); inclusive sobre a forma na qual deve ocorrer a oitiva, conforme versa Filho (2010):

O auto do interrogatório será subscrito pelo Escrivão e assinado pela Autoridade Policial, pelo indiciado e por duas testemunhas. Não há necessidade de as testemunhas assistirem ao interrogatório. O próprio texto legal frisa: "... e assinado por duas testemunhas que the tenham ouvido a leitura". Independentemente da presença dessas duas

RC: 106499

Disponível em: https://www.nucleodoconhecimento.com.br/lei/pratica-doprocedimento 
testemunhas que devem assistir a leitura do interrogatório e, após subscrevê-lo, se o indiciado não quiser ou não souber assinar seu nome, ad cautelam, deverá a Autoridade Policial, por aplicação analógica, determinar seja tal fato consignado no final do auto do interrogatório, como, aliás, prescreve o art. 195 do CPP.

Como já tratado anteriormente, com a alteração da Lei oํ 13.245/2016 houve a possibilidade de o advogado estar presente junto ao seu cliente em todos os atos que o mesmo venha a comparecer, em especial na oitiva do investigado. Todavia, devese atentar para o fato de que a novidade não tornou obrigatória a presença do advogado/defensor na ocorrência do interrogatório, mas consistiu em apenas conferir um direito ao mesmo em assistir seu cliente no depoimento (GIORDA, 2017).

No caso de não ser conhecido o autor do delito logo com o recebimento da queixa ou da denúncia de um crime, será necessário o reconhecimento das pessoas e coisas, em geral envolvidas. Essa disposição vem prevista no inciso VI que traz ainda a possibilidade da realização de acareações, que segundo Milanez (2016) é um "[...] mecanismo jurídico processual pelo qual duas ou mais pessoas são colocadas frente a frente para esclarecerem divergências relevantes em suas declarações".

De modo a iniciar a persecução criminal e nortear por qual caminho deverá seguir a linha de investigação, a autoridade policial terá de apresentar à vítima e as testemunhas, álbuns fotográficos com as imagens de criminosos, sendo tal procedimento meio legítimo de se tentar atribuir uma identidade ao sujeito cometedor da delinquência (MOUGENOT, 2019).

No inciso VII do artigo em estudo, o legislador evidencia a importância de sempre se realizar o exame de corpo de delito nos casos em que o crime deixar vestígios (caso não seja possível colher os indícios, poderão os mesmos serem substituídos por prova testemunhal). Tal procedimento, evidentemente, não pode substituir a confissão do investigado nos crimes de natureza material, sendo cabível que se ofereça a denúncia e se receba a mesma ainda que desacompanhada de laudo de perícia, sendo, no entanto, impossível que haja a condenação sem essa prova, portanto, deve se juntar tal parecer até o término da instrução (MARCÃO, 2016).

RC: 106499

Disponível em: https://www.nucleodoconhecimento.com.br/lei/pratica-doprocedimento 
O inciso VIII dispõe sobre a identificação do indiciado, que deve ocorrer por meio de identificação datiloscópica (se possível) e fazer juntar aos autos sua folha de antecedentes. Necessita-se atentar que tal disposição entrou no ordenamento jurídico antes da carta magna de 1988 que traz expressamente nos moldes do artigo 5으, LVIII "o civilmente identificado não será submetido à identificação criminal, salvo nas hipóteses previstas em lei" (LOPES e SILVA, 2020).

Para que o Estado possa punir efetivamente o cometedor do crime, é necessário que ele tenha conhecimento seguro sobre a correta identificação do autor. Dessa forma, é muito comum na ocorrência diária policial que o suspeito omita seus dados pessoais, apresente informações controversas ou até mesmo documentos falsos, a fim de confundir a autoridade policial. Por isso é necessária a identificação criminal, porque por meio dela é realizado o registro dos dados que identificam a pessoa realizadora do crime, evitando que haja imputações injustas e constrangimentos desnecessários (LIMA, 2017).

Conforme leciona Nucci (2016):

É certo que muitos policiais exorbitaram seus poderes e, em vez de garantir ao indiciado uma colheita corriqueira do material datiloscópico, transformaram delegacias em lugares de acesso da imprensa, com direito à filmagem e fotos daquele que seria publicamente indiciado, surpreendido na famosa situação de "tocar piano". Ora, por conta da má utilização do processo de identificação criminal, terminou-se inserindo na Constituição uma cláusula pétrea que somente trouxe problemas, especialmente ao deixar de dar garantia ao processo penal de que se está acusando a pessoa certa. Bastaria, se esse fosse o desejo, que uma lei fosse editada, punindo severamente aqueles que abusassem do poder de indiciamento, especialmente dando publicidade indevida ao ato, para que se resolvesse o problema. Ao contrário disso, preferiu-se o método mais fácil, porém inconveniente: quem já possuísse identificação civil não mais seria identificado criminalmente, gerando muitos erros judiciários, atualmente amplamente divulgados e comprovados, pois a subtração de documentos civis (RG) alheios tornou-se comum e criminoso passaram a apresentar aos delegados falsificações perfeitas, colocando em seus lugares, inocentes.

RC: 106499

Disponível em: https://www.nucleodoconhecimento.com.br/lei/pratica-doprocedimento 
Cabe destacar, além disso, o pensamento de Távora e Alencar (2017), que discorrem que as informações colhidas podem, ainda, interferir em eventual qualificadora, concessão de privilégios ou qualquer circunstância que tenha algum grau de influência na hora de fixar a pena pelo magistrado.

\subsection{REPRODUÇÃO SIMULADA DOS FATOS}

De acordo com o que expressa o artigo $7^{\circ}$ do Código Processual Penal, a autoridade policial possui discricionariedade para realizar ou não a reprodução simulada dos fatos, desde que não contrarie a moralidade ou ordem pública. Entretanto, deve se atentar a alguns detalhes no momento da realização do ato, primeiramente que não seja realizado quando puder acabar servindo como uma maneira didática de se ensinar a praticar a infração penal, segundo, que o Delegado deve estar acompanhado de dois peritos no momento da reconstituição do ato, para que os mesmos possam registrar tudo e elaborar no final um laudo a respeito (BRITO; FABRETI, 2015).

Além disso, cumpre salientar que o acusado não é obrigado a comparecer na reprodução simulada, pois segundo entendimento do Supremo Tribunal Federal, ninguém é obrigado a constituir prova contra si mesmo (MOUGENOT, 2019). Nesse sentido, o acusado não pode ser conduzido coercitivamente para participar da reprodução.

Sobre esse assunto, Capez (2016) trata ainda que o investigado poderá ser obrigado a estar presente no momento da reconstituição, mas não poderá ser obrigado a participar da mesma, sendo tal direito respaldado pelos constitucionalmente garantidos direito ao silêncio e ao direito de não ser obrigado a produzir provas contra si mesmo. 


\subsection{DO INDICIAMENTO}

$\mathrm{O}$ ato de indiciamento é ato privativo da Autoridade Policial, não sendo possível que o juiz ou o promotor público interfira nessa decisão. Sendo assim, não é possível a requisição ou determinação para indiciar, cabendo ao delegado de acordo com seu convencimento sobre a autoria dos fatos, baseado nas provas colhidas na fase investigativa.

O indiciamento é a etapa na qual o Delegado de Polícia (único responsável pelo indiciamento) depois de formada sua convicção e acreditando que a fase de reunir elementos probatórios sobre a ocorrência do delito tenha se encerrado, determinar quem é o responsável pela autoria do crime investigado (ANSELMO, 2015).

Sobre esse conceito de indiciamento, ensina Nucci (2016):

Indiciado é a pessoa eleita pelo Estado-investigação, dentro da sua convicção, como autora da infração penal. Ser indiciado, isto é, apontado como autor do crime pelos indícios colhidos no inquérito policial, implica um constrangimento natural, pois, a folha de antecedentes receberá a informação, tornando-se permanente, ainda que o inquérito seja, posteriormente, arquivado. Assim, o indiciamento não é um ato discricionário da autoridade policial, devendo basear-se em provas suficientes para isso.

Analisando o indiciamento com base nessa visão apresentada, consegue-se extrair importante fundamento acerca do ato: a importância do investigado saber que ele passa a ser então, o principal suspeito do cometimento do delito.

Só é indicado esse tipo de indiciamento, o qual é realizado no momento da produção do relatório final, quando o futuro indiciado já tiver sido ouvido durante o feito (através de depoimento e tendo sido cientificado acerca de seus direitos), pois, nessas circunstâncias, não haveria necessidade de produção de uma nova intimação apenas para que o suspeito venha a ser indiciado de forma presencial. Este entendimento se baseia nos princípios da economia processual e da celeridade (SILVA, 2018). 


\section{CONSIDERAÇÕES FINAIS}

O inquérito policial são as diligências realizadas pela autoridade policial na apuração de infrações penais. Todavia, para elucidar as considerações desse estudo foi resgatado a pergunta norteadora: como ocorre o desenvolvimento do inquérito policial e quais são suas principais características? Baseando-se nessa premissa, o presente trabalho teve por objetivo discutir aspectos importantes relacionados ao procedimento e como ele é imprescindível para analisar as evidências, oferecendo um grande respaldo para propor uma ação penal. As informações descritas foram embasadas na literatura disponível nos bancos dados que indexam as publicações acadêmicas e no material disponível na internet, em sites que tratam e discutem essa problemática.

O trabalho demonstrou como se desenvolve o inquérito policial, se embasando na literatura já publicada, entretanto, a diversos pontos que poderiam ser levados em consideração para complementar os resultados, tal como aplicar uma pesquisa de campo para aferir se esse procedimento é difundido no setor de forma satisfatória, aferir se quais são as suas fragilidades e quais pontos poderiam ser revistos.

O trabalho evidenciou que na literatura disponível, os autores focam principalmente na fase processual, não levando em consideração o inquérito policial, pois o mesmo que dá subsídio para a ação penal e as informações ali produzidas apresentam um aspecto capaz de gerar convencimento sobre os elementos do delito, ficando claro que o procedimento judicial deve ser repetido, para se obter um caráter de prova mais robusto.

Também ficou nítido neste trabalho que as diligências realizadas pela autoridade policial têm caráter fundamental na futura produção probatória que será feita em caráter judicial e a não observância dos cuidados necessários em sua produção poderá gerar efeitos perigosos em sede de juízo (como, por exemplo recolher uma amostra vestigial que passará por perícia, sem as devidas precauções).

Disponível em: https://www.nucleodoconhecimento.com.br/lei/pratica-doprocedimento 
Nesse diapasão, torna-se nítido o entendimento de que todos os principais atos e dispositivos concernentes ao sistema de investigação, incluindo-se o inquérito policial e o procedimento investigatório criminal, caminham para um crescimento gradual de sua importância aos olhos dos operadores do direito.

Os achados deste trabalho podem e devem ser usados como apoio para uma literatura diversa e que trate da temática de diferentes perspectivas, podendo ser usada como base para estudos complementares que venham a confirmar ou refutar os resultados aqui descritos, e as principais informações abordadas podem ser utilizadas para desenvolver materiais de divulgação, e para demonstrar a relevância desse tópico para o direito.

\section{REFERÊNCIAS}

ANSELMO, M. A. Ato do indiciamento deve ser devidamente fundamentado. Consultor Jurídico, 2015. Disponível em< https://www.conjur.com.br/2015-out13/academia-policia-ato-indiciamentodevidamente-fundamentado> Acesso em $18 / 01 / 2022$.

AVENA, N. C. P. Processo penal. São Paulo: MÉTODO, 2017.

BRASIL. Lei no 8.906, de 4 de julho de 1994. Dispõe sobre o Estatuto da Advocacia e a Ordem dos Advogados do Brasil (OAB). Disponível em < http://www.planalto.gov.br/ccivil_03/Leis/L8906.htm> Acesso em 18/01/2022.

BRASIL. Constituição da República Federativa do Brasil de 1988. Constituição de 1988,1988 disponível em http://www.planalto.gov.br/ccivil_03/constituicao/constituicao.htm> Acesso em 18/01/2022.

BRASIL. Decreto Lei ํㅜ 2.848, de 7 de dezembro de 1940. Código Penal Brasileiro. Disponível em $\quad<\quad$ http://www.planalto.gov.br/ccivil_03/decretolei/del2848compilado.htm>Acesso em 18/01/2022.

RC: 106499

Disponível em: https://www.nucleodoconhecimento.com.br/lei/pratica-doprocedimento 
BRASIL. Decreto-lei no 3.689, de 3 de outubro de 1941. Código de Processo Penal. Disponível em < http://www.planalto.gov.br/ccivil_03/decreto-lei/del3689.htm> Acesso em 18/01/2022.

BRASIL. Lei 13.245, de 12 de janeiro de 2016. Estatuto da Ordem dos Advogados do Brasil. Disponível em< http://www.planalto.gov.br/ccivil_03/_ato20152018/2016/lei//13245.htm> Acesso em 18/01/2022.

BRITO, A. C; FABRETI, M. A. F. L. B. Processo Penal brasileiro. São Paulo: Atlas, 2015.

CAPEZ, F. Processo Penal. 23a edição. rev. e atual. São Paulo: SARAIVA, 2016.

DUARTE, G. A. As principais características do inquérito policial. Conteúdo Jurídico, 2014. Disponível em< https://conteudojuridico.com.br/consulta/Artigos/42055/asprincipais-caracteristicas-do-inquerito-policial > Acesso em 18/01/2022.

FILHO, F. C. T. Processo Penal. São Paulo: Saraiva, 2010.

GIORDA, M. F. B. M. P. Obrigatoriedade de advogado em interrogatório policial: posição contrária. Jornal Carta Forense, 2017. Disponível em< http://www.cartaforense.com.br/conteudo/artigos/obrigatoriedade-deadvogado-eminterrogatorio-policial-posicao-contraria/17809 > Acesso em 18/01/2022.

JUNIOR, J. M. S. Características do Inquérito Policial. DireitoNet, 2016 Disponível em $<$ https://www.direitonet.com.br/artigos/exibir/9806/Caracteristicas-do-inqueritopolicial> Acesso em 18/02/2022.

JUNIOR, R. A. S. Inquérito Policial: Indagações, doutrina, jurisprudência, prática. São Paulo: Saraiva, 1998. 
LIMA, E C. Afinal, o que é Indiciamento? Canal Ciências Criminais, 2017. Disponível em< https://canalcienciascriminais.jusbrasil.com.br/artigos/419563831/afinal-o-que-eoindiciamento> Acesso em 18/01/2022.,

LIMA, R. B. Manual de processo penal: volume único. Salvador: JusPodivm, 2017.

LOPES, M. F; SILVA, M. S. Identificação Criminal. Politize,2020. Disponível em < https://www.politize.com.br/artigo-5/identificacao-

criminal/\#: :text=O\%20inciso\%20LVIII\%20do\%20artigo,nas\%20hip\%C3\%B3teses\% 20previstas\%20em\%20lei.> Acesso em 18/01/2022.

MARCÃO, R. Código de Processo Penal comentado. São Paulo: Saraiva, 2016.

MILANEZ, B. O que se entende por acareação no processo penal? Jusbrasil, 2016. Disponível em < https://canalcienciascriminais.jusbrasil.com.br/artigos/395518910/oque-se-entende-por-acareacao-no-processo-

penal\#: :text=A\%20acarea\%C3\%A7\%C3\%A30\%20\%2D\%20mecanismo\%20jur\%C3 \%ADdico\%20processual,mais\%20questionada\%20em\%20\%C3\%A2mbito\%20jur\%C 3\%ADdico.> Acesso em 18/01/2022.

MOUGENOT, E. Curso de Processo Penal. São Paulo: Saraiva, 2019.

NETO, F. S. Inquérito Policial exerce importante função restaurativa. Jusbrasil, 2018. Disponível em< https://canalcienciascriminais.jusbrasil.com.br/artigos/529984671/inquerito-policialexerce-importante-funcaorestaurativa\#: :text=A\%20doutrina\%20tradicional\%20sempre\%20destacou,p.> Acesso em 1801/2022.

NUCCI, G. S. Código de Processo Penal comentado. Rio de Janeiro: Forense, 2016.

PACELLI, E. Curso de Processo Penal. São Paulo: Atlas, 2017. 
PATRIOTA, C. C. S. R. Forma de tramitação do inquérito policial. Jus, 2017. Disponível em < https://jus.com.br/artigos/56124/forma-de-tramitacao-do-inqueritopolicial\#: : :text=O\%20sigilo\%20no\%20inqu\%C3\%A9rito\%20policial,exigido\%20pelo \%20interesse\%20da\%20sociedade > Acesso em 18/01/2022.

PICOLIN, G. R. Inquérito Policial. JurisWay Sistema Educacional Online,2007. Disponível em < https://www.jurisway.org.br/v2/dhall.asp?id_dh=157> Acesso em 18/01/2022.

SILVA. F. C. A. Análise da atuação do conselho nacional de justiça no monitoramento e avaliação de políticas judiciárias - ENAPE. Brasília: Tese de Especialização em Gestão Pública, 2018.

SOUZA, K. J. A lei no 13.245/16 e seus reflexos nos procedimentos investigatórios. Jus, 2016. Disponível em < https://jus.com.br/artigos/66530/a-lei-n-13-245-16-e-seusreflexos-nos-procedimentos-investigatorios> Acesso em 18/01/2022.

STF. Súmula vinculante 14. Sessão Plenária de 02/02/2009. Supremo Tribunal Federal, 2009. Disponível em < https://jurisprudencia.stf.jus.br/pages/search/seqsumula762/false> Acesso em 18/01/2022.

STF. Medida Cautelar Na Ação Direta de Inconstitucionalidade 6299 Distrito Federal. Supremo Tribunal Federal, 2001. Disponível em < https://www.conjur.com.br/dl/fuxliminar-juiz-garantias-atereferendo.pdf > Acesso em 18/01/2022.

TÁVORA, N; ALENCAR, R. R. Curso de direito processual penal. Salvador: JusPodivm, 2017.

Enviado: Janeiro, 2022.

Aprovado: Fevereiro, 2022.

RC: 106499

Disponível em: https://www.nucleodoconhecimento.com.br/lei/pratica-doprocedimento 